\title{
New Model and Guidelines for the Evaluation of Different Cartographic Products
}

\author{
Stanislav FRANGEŠ, Damir ŠANTEK, Darko FUDURIĆ
}

\begin{abstract}
First complete review form is introduced in which all cartographic products are provided in a way that cartographic experts and non-experts are able to simply do a cartographic products evaluation according to the selected review type: simple (or short) - faster to accomplish, or complex (or long, complete) - more informationdemanding type of the review. It is up to the reviewer which type of the review he/she will finally select - and this determines the set of the information that can be provided as a part of the review. The idea is finalized and tested through the web application, along with the one true cartographic product evaluation as working example. Evaluation and procedure process presented here was tested on a cartographic product- map of Mljet made by one of the authors of this paper.
\end{abstract}

Keywords: cartography; cartographic product; evaluation; map; review

\section{INTRODUCTION}

According to available literature, the authors have found no standardised type of form for reviewers to facilitate the process of evaluating different cartographic products. The whole idea behind this research and the publishing of this paper is built upon the need for a standardised form for reviewing map products. Balanced criteria for reviewing and evaluating the quality of certain map products should be achieved in this way.

The years 2015 and 2016 were the International Map Years [1], which presented an additional motive and opportunity for designing a standardised form that would be suitable for today's many different map products, along with accompanying publishing material.

This categorisation was adopted at the international cartography symposium held as a part of the International
Cartography Conference in Rio de Janeiro [2]. Norms and rules for the evaluation and review of cartographic products are proposed in this paper for the first time. Achieving this goal proved to be more complex than we had expected at the beginning of the research, because a whole spectrum of versatile map presentations needed to be included, with the most accurate analysis to provide objective evaluation of different map products. In addition, the categorisation of map products defined and accepted by the International Cartography Association (ICA) was taken into consideration, as proposed by cartography experts and researchers from around the world. We are planning to propose the adoption of these cartographic product review forms based on the norms and rules presented here at the next ICA 2019 event, which will be organised in Tokyo.

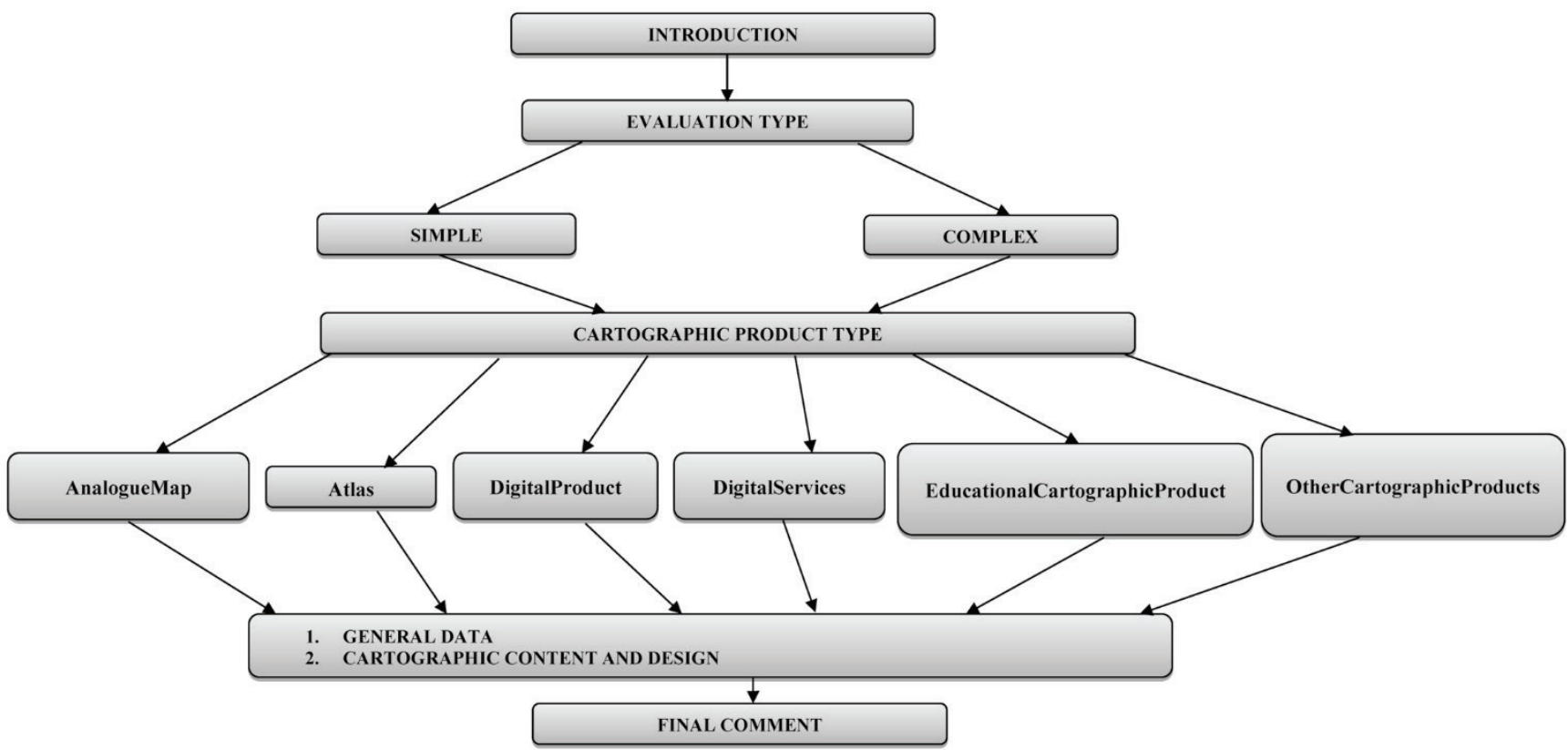

Figure 1 Sequence of the forms during the evaluation process of different map products

According to the papers published so far which deal with the set of problems identified concerning the design of the review forms [3]-[6], the form named Map Evaluation Guidelines from ESRI [7], the overview and analysis of different cartographic presentations published in the Cartography and Geoinformation journal (Cro. Kartografija i geoinformacije) [8]-[18], as well as our own experience, we decided to design evaluation forms for cartographic products and propose them to be used for a wide range of projects of reviewing cartographic products, 
such as reviewing maps for the purpose of publishing them in journals. It is possible to accept and use standardised forms suitable for all already known map products.

\section{THE CONCEPT OF EVALUATION}

When drafting the proposed forms, we wanted to summarise and simplify the elements undergoing evaluation, while not ignoring or leaving out anything important and necessary, mainly in accordance with the general rules of drafting cartographic products and evaluating those products.

The evaluation process begins with the introductory part in which, along with all mandatory parts, the type of evaluation and map product are selected, which selection defines the other phases of the evaluation process. Filling out the general form is the next phase, along with describing the map content and design of the map product being reviewed, with the final phase that includes the final review comment about the map product. A scheme of the form flow during the evaluation process of different map products is shown in Fig. 1.

\section{INTRODUCTORY FORM}

The forms containing all elements proposed for the purpose of evaluation are explained later in this paper, while the full evaluation is available on: http:/www.dinamika.hr/rec, using user e-mail address: rec@recs.com and user password: "rec".

Before entering the data required in the introductory form, it is possible to delete or edit the existing reviews previously saved in the database or write a new review by filling out the form fields. Mandatory fields are marked in blue.

In the introductory part of the review of cartographic products (Fig. 2), it is mandatory to enter the reviewer's name and the place of review (the date is automatically added to the review during the process of the reviewer's logging in and filling out the review form). The other nonmandatory introductory form data are: the reason for reviewing, the purpose, the expected users of the review, and the terms of cartographic product use. Each reviewer (editor of the review) can load and edit all their reviews stored in the database, and all changes can be saved in the database later. All reviews are available only to the reviewer and system administrator. System administrators can see all reviews stored in the database and manage them by the reviewer.

The next mandatory data to be entered is the type of review, which can be either simple review (therefore faster, with less data to enter) or complex review (including more data and therefore time consuming), which includes a large number of elements of the cartographic product.

After the type of review has been selected, it is mandatory to choose the cartographic product type, which can be one of the following: analogue map, atlas, digital product, digital service, educational map product or any other map product.

Depending on the simple (and shorter) or complex (and larger) review type, and the selected type of cartographic product, the reviewer may continue to fill out the first part of the review form with general information, which present the main map elements, and the second part of the review form, with cartographic content and composition.
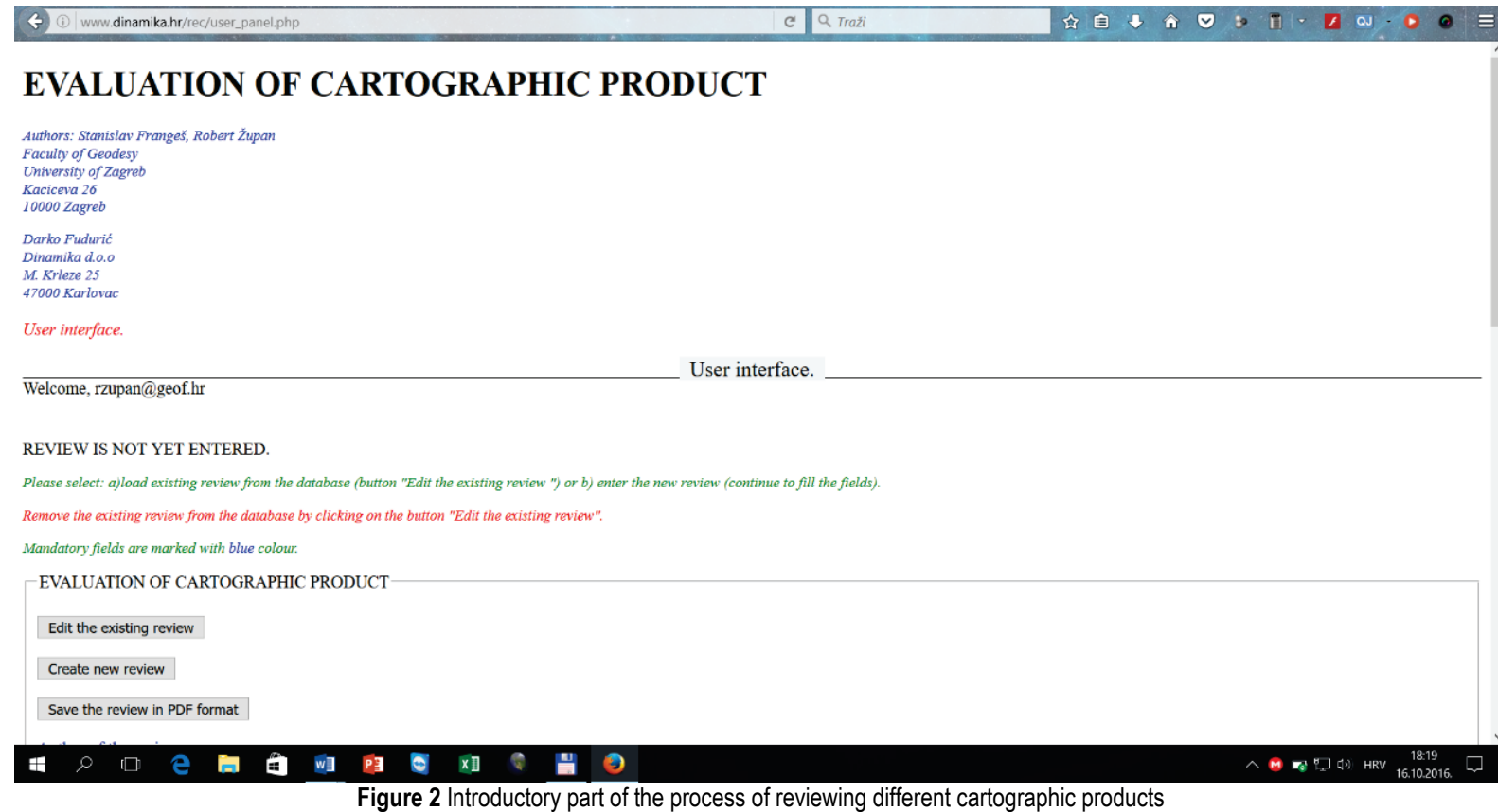

\section{GENERAL INFORMATION FORM}

After filling out the introductory form, the form with general information can be filled out, and this information describes the main elements of different cartographic products. Additionally, for each such element, the editor can choose if the element is applied or not on the selected type of cartographic product. In Tabs. 1 and 2, these elements are marked in green (green fields). After this, the editor can select if the element is applied appropriately or that is not the case.

For some elements (for example, size/dimension or material the cartographic product is made of), it does not need to be selected if they are applied on the map or not, 
but it is only important to note if the element is applied appropriately. In Tab. 1, such cases are marked in yellow.

If the editor thinks that would be useful, for each element in the form it is also possible to enter additional explanation or notes.
The proposed reviewing process allows having different information included in the review depending on the selected review type - simple or complex, and the type of cartographic product. Tab. 1 lists the elements included in simple review.

Table 1 Elements of different cartographic products contained in the simple review

\begin{tabular}{|c|c|c|c|c|c|c|c|c|c|c|c|c|c|c|c|c|c|c|c|}
\hline \multirow{2}{*}{ 省䝿 } & \multirow[b]{2}{*}{ 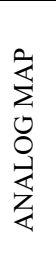 } & \multirow[b]{2}{*}{ 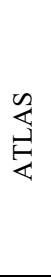 } & \multicolumn{6}{|c|}{ DIGITAL PRODUCT } & \multicolumn{3}{|c|}{$\begin{array}{l}\text { DIGITAL } \\
\text { SERVICES }\end{array}$} & \multicolumn{7}{|c|}{$\begin{array}{c}\text { EDUCATIONAL CARTOGRAPHIC } \\
\text { PRODUCT }\end{array}$} & \multirow{2}{*}{ 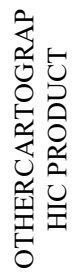 } \\
\hline & & & 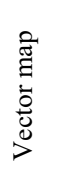 & 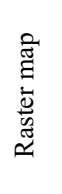 & 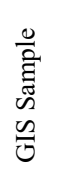 & 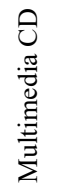 & 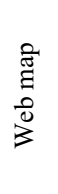 & 句 & $\sum_{i}^{\infty}$ & $\sum_{1}^{\infty}$ & $\sum_{i}^{\infty}$ & 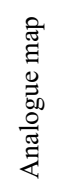 & $\frac{a}{\frac{a}{\pi}}$ & 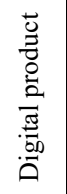 & 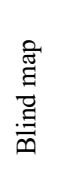 & $\frac{8}{0}$ & 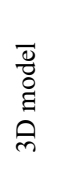 & $\stackrel{\bar{\Xi}}{\grave{0}}$ & \\
\hline \multicolumn{20}{|l|}{ Caption (name) } \\
\hline \multicolumn{20}{|l|}{ Scale } \\
\hline \multicolumn{20}{|l|}{ Coordinate grid } \\
\hline \multicolumn{20}{|l|}{$\begin{array}{l}\text { Markup for } \\
\text { North direction }\end{array}$} \\
\hline \multicolumn{20}{|l|}{$\begin{array}{l}\text { Author (editor, } \\
\text { maker) }\end{array}$} \\
\hline \multicolumn{20}{|l|}{ Publication Date } \\
\hline \multicolumn{20}{|l|}{$\begin{array}{l}\text { Dimension } \\
(\text { size })\end{array}$} \\
\hline \multicolumn{20}{|l|}{ Material } \\
\hline \multicolumn{20}{|l|}{$\begin{array}{l}\text { Number of } \\
\text { pages }\end{array}$} \\
\hline \multicolumn{20}{|l|}{ Number of maps } \\
\hline \multicolumn{20}{|l|}{ Format } \\
\hline \multicolumn{20}{|l|}{$\begin{array}{l}\text { Software } \\
\text { platform }\end{array}$} \\
\hline \multicolumn{20}{|l|}{ Resolution } \\
\hline \multicolumn{20}{|l|}{ Size (MB, GB) } \\
\hline \multicolumn{20}{|l|}{ URL address } \\
\hline \multicolumn{20}{|l|}{$\begin{array}{l}\text { Educational } \\
\text { level purpose }\end{array}$} \\
\hline \begin{tabular}{l|l}
$\begin{array}{l}\text { It is mand } \\
\text { element is }\end{array}$ \\
\end{tabular} & & appro & iately & & & & & & & & & & & & & addit & & & \\
\hline $\begin{array}{l}\text { It is not } \mathrm{m} \\
\text { element is }\end{array}$ & ppliec & & $\mathrm{k}$ if $\mathrm{t}$ & s elen & ent is & pplied & br not & $\mathrm{n}$ this & & cartog & aphic & roduc & Add & & & andatc & & & \\
\hline Nothing is & handa & ry on & he res & ew fol & $\mathrm{a}$ and & othin & can b & enter & & & & & & & & & & & \\
\hline
\end{tabular}

In Tab. 2, the basic elements of different cartographic products are given included in complex review. In case of complex review, the editor answers all the questions listed in Tab. 1 and Tab. 2.

\section{CARTOGRAPHIC CONTENT AND COMPOSITION FORM}

Regardless of the review type (simple or complex), the form on cartographic content and composition is filled out following the review form with general-purpose data. This content also depends on the review type, which can be either simple or complex.

In Tab. 3, the elements of cartographic content and composition are given included in simple review of different cartographic products.

In this case, for the elements "Display Area" and "Map elements position", it only matters "if a certain element is applied appropriately or not". The question "is this element applied on the map or not" is not relevant, but is still relevant for all other elements. If the reviewer chooses to fill out complex review of cartographic content and design in addition to the elements covered by simple review, as shown in Tab. 3, it is necessary to answer the questions shown in Tab. 4.

As for the question regarding the map field review, the form does not require an answer about whether or not it is applied to the map, but it only confirms if the element in question is applied appropriately, while for all other elements the reviewer answers about the elements' application and whether it has been done appropriately. Tab. 3 and Tab. 4 can be found on https://mega.nz/\#!EYoWXbTb!V2Kqm7eu3Yk99K2KMl bhRdPsyJXvs9c8nf5C1mcQdok.

\section{FINAL COMMENT}

After filling out all the necessary data for the appropriate type of cartographic products in the appropriate forms there is a possibility to give a final comment by filling evaluation form, which consists of several general subjective impressions of cartographic work, such as originality, curiosity, but also what is needed to make the product acceptable for publication and at the end overall assessment of the whole. Reviewer enters these data as a description in the text field below the questions.

\section{APPLICATION OF EVALUATION PROCEDURE ON A PRACTICAL EXAMPLE FOR THE MAP OF NP MLJET}

As a practical example, which will be applied to check the evaluation process, we decided to use an analogue or paper map of the Mljet National Park that we continuously 
published from 1987 to 2014 for tourist purposes of the National Park. Fig. 3 shows the map of the Mljet National Park reduced in scale. Fulfilled peer review forms for that map NP Mljet at http://www.dinamika.hr/rec/mljet.pdf can be found online at: http://www.dinamika.hr/rec/simple.pdf and http://www.dinamika.hr/rec/complex.pdf.

Table 2 Basic elements of different cartographic products included in complex review

\begin{tabular}{|c|c|c|c|c|c|c|c|c|c|c|c|c|c|c|c|c|c|c|c|}
\hline \multirow[b]{2}{*}{ 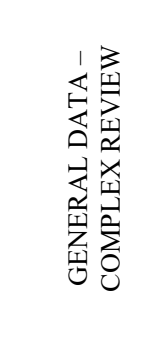 } & \multirow[b]{2}{*}{ 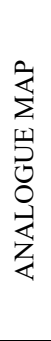 } & \multirow[b]{2}{*}{ 先 } & \multicolumn{6}{|c|}{ DIGITAL PRODUCT } & \multicolumn{3}{|c|}{$\begin{array}{c}\text { DIGITAL } \\
\text { SERVICES }\end{array}$} & \multicolumn{7}{|c|}{$\begin{array}{c}\text { EDUCATIONAL CARTOGRAPHIC } \\
\text { PRODUCT }\end{array}$} & \multirow{2}{*}{ 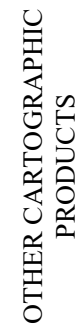 } \\
\hline & & & 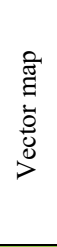 & 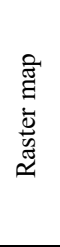 & 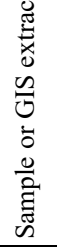 & 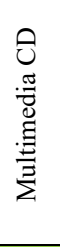 & 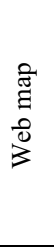 & 离 & $\sum_{3}^{\infty}$ & 先 & $\sum_{3}^{\infty}$ & 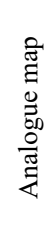 & $\frac{\pi}{\mathbb{Z}}$ & 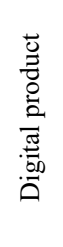 & 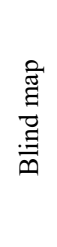 & $\frac{n}{0}$ & $\begin{array}{l}\bar{\Xi} \\
\overline{0} \\
\vdots \\
\text { m }\end{array}$ & $\begin{array}{l}\bar{\Xi} \\
\overline{0}\end{array}$ & \\
\hline \multicolumn{20}{|l|}{ Subtitle } \\
\hline \multicolumn{20}{|l|}{ Nomenclature } \\
\hline \multirow{2}{*}{\multicolumn{20}{|c|}{$\begin{array}{l}\text { Projection } \\
\text { Ellipsoid }\end{array}$}} \\
\hline & & & & & & & & & & & & & & & & & & & \\
\hline \multicolumn{20}{|l|}{ Author rights } \\
\hline \multicolumn{20}{|l|}{$\begin{array}{l}\text { Printing and } \\
\text { copyrights }\end{array}$} \\
\hline \multicolumn{20}{|l|}{ Publisher } \\
\hline \multicolumn{20}{|l|}{ Issue number } \\
\hline \multicolumn{20}{|l|}{ Circulation } \\
\hline \multicolumn{20}{|l|}{ Print type } \\
\hline \multicolumn{20}{|l|}{$\begin{array}{l}\text { Publisher } \\
\text { Company }\end{array}$} \\
\hline \multicolumn{20}{|c|}{ Publishing Date } \\
\hline \multicolumn{20}{|l|}{ Sources } \\
\hline $\begin{array}{l}\text { Titles of the } \\
\text { adjacent sheets }\end{array}$ & & & & & & & & & & & & & & & & & & & \\
\hline $\begin{array}{l}\text { Nomenclatures } \\
\text { of the adjacent } \\
\text { sheets }\end{array}$ & & & & & & & & & & & & & & & & & & & \\
\hline $\begin{array}{l}\text { Meridian } \\
\text { convergence } \\
\text { and magnetic } \\
\text { declination }\end{array}$ & & & & & & & & & & & & & & & & & & & \\
\hline $\begin{array}{l}\text { Intellectual } \\
\text { Property }\end{array}$ & & & & & & & & & & & & & & & & & & & \\
\hline Explanation & & & & & & & & & & & & & & & & & & & \\
\hline Storage type & & & & & & & & & & & & & & & & & & & \\
\hline Maintenance & & & & & & & & & & & & & & & & & & & \\
\hline Last update & & & & & & & & & & & & & & & & & & & \\
\hline $\begin{array}{l}\text { Index or list of } \\
\text { objects }\end{array}$ & & & & & & & & & & & & & & & & & & & \\
\hline Diagrams & & & & & & & & & & & & & & & & & & & \\
\hline Graphs & & & & & & & & & & & & & & & & & & & \\
\hline Review & & & & & & & & & & & & & & & & & & & \\
\hline Lecture & & & & & & & & & & & & & & & & & & & \\
\hline Multilingual & & & & & & & & & & & & & & & & & & & \\
\hline Other data & & & & & & & & & & & & & & & & & & & \\
\hline Layers & & & & & & & & & & & & & & & & & & & \\
\hline Zoom & & & & & & & & & & & & & & & & & & & \\
\hline Search & & & & & & & & & & & & & & & & & & & \\
\hline Interaction & & & & & & & & & & & & & & & & & & & \\
\hline Animation & & & & & & & & & & & & & & & & & & & \\
\hline User's guide & & & & & & & & & & & & & & & & & & & \\
\hline Service purpos & & & & & & & & & & & & & & & & & & & \\
\hline $\begin{array}{l}\text { WEB } \\
\text { Publishing Dat }\end{array}$ & & & & & & & & & & & & & & & & & & & \\
\hline Metadata & & & & & & & & & & & & & & & & & & & \\
\hline $\begin{array}{l}\text { Search by } \\
\text { object groups } \\
\text { and objects }\end{array}$ & & & & & & & & & & & & & & & & & & & \\
\hline
\end{tabular}




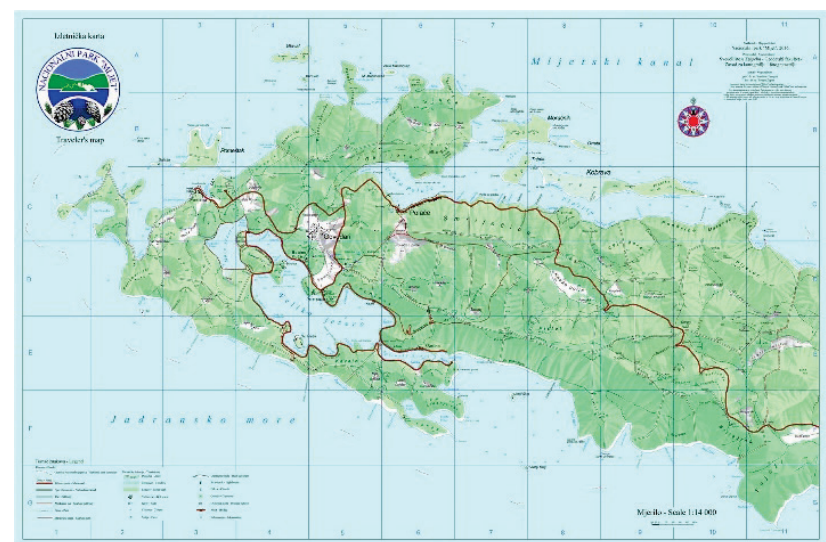

Figure 3 Map of the Mljet National Park shown here reduced in scale, which has been used to check the evaluation process

\section{CONCLUSION}

To our knowledge, there have been no formal peer review forms for map review so far. This can be attributed to a large variety of cartographic products, as well as a variety of cartographic products within a single product category, which makes it relatively difficult to include everything within a single review process. This is why this paper gives a specific proposal to comprehensively cover the evaluation of cartographic products used in practice today, as shown in the evaluation process of the analogue Mljet National Park map. The website mentioned above can be accessed with filled-out review forms containing the evaluation of the Mljet National Park map, as it would be impossible to present this in this paper due to the limited number of pages. The presented evaluation shows the advantages or good sides, as well as the disadvantages of the above examples of the Mljet National Park map through peer-review questions and comments (preferably) entered by cartographic experts. The proposed forms for review of cartographic products are available to everyone online at the link above. We hope that, in the future, map review processes will encourage debate among cartographic experts about the need for a standardisation of similar recurring processes, as the emergence of new cartographic products requires mandatory updates of the review forms or the entire review process.

\section{Acknowledgements}

We would like to thank everyone who has contributed in their own way to the realisation of this project, with special thanks to the employees of NP Mljet. This work was supported by the University of Zagreb under Grant number class: 641-01/16-03/5, ID: 380-020/081-16-02.

\section{REFERENCES}

[1] IMY: International Map Year 2015. http://internationalmapyear.org/ (10. 03. 2017)

[2] ICA: Guide for Participation in the International Cartographic Exhibition. 27th International Cartographic Conference, $16^{\text {th }}$ General Assembly, Rio de Janeiro - Brasil, August, 23-28. 2015. http://www.icc2015.org/ICC2015_ Map_Exhibition_Guide.pdf (10.03. 2017)

[3] ESRI: Using a mapmaking checklist for map design. 2012. http://blogs.esri.com/esri/arcgis/2012/05/03/using-amapmaking-checklist-for-map-design/ (10.03. 2017)
[4] GEOG 118: Design checklist and evaluation criteria. $2012-$ 2014. http://www.s4.brown.edu/S4/Training/Modull/ Reading/designchecklist.pdf (10. 03. 2017)

[5] Ladniak, W. \& Kałamucki, K. (2007). The criteria of comprehensive evaluation of maps in the internet. Proceedings of the $23^{\text {rd }}$ Intern. Cartographic Conference, http://icaci.org/files/documents/ICC_proceedings/ICC2007/ documents/doc/THEME\%2012/Oral\%209/THE\%20CRITE RIA\%20OF\%20COMPREHENSIVE\%20EVALUATION $\% 20 \mathrm{OF} \% 20 \mathrm{MAPS} \% 20 \mathrm{IN} \% 20 \mathrm{THE} \% 20 \mathrm{INTE}$.doc. (10. 03. 2017)

[6] Makram Murad-al-Shaikh, M. (2013). How Much Instructions are needed for a Good GIS Map. http://icaci.org/files/documents/ICC_proceedings/ICC2013/ extendedAbstract $/ 387$ proceeding.pdf (27. 05. 2015)

[7] ESRI. Map Evaluation Guidelines. (2007). http://downloads.esri.com/MappingCenter2007/arcGISReso urces/more/MapEvaluationGuidelines.pdf (10. 03. 2017.)

[8] Faričić, J. (2004). Atlas svijeta za 21. stoljeće. Kartografija $i$ geoinformacije, 3(3), 108-109. http://hrcak.srce.hr/2410 (10. 03. 2017) (in Croatian)

[9] Frančula, N. (2005). Interaktivna fotokarta Švicarske. Kartografija $i$ geoinformacije, 4(4), 140-141. http://hrcak.srce.hr/2365 (10. 03. 2017) (in Croatian)

[10] Poslončec-Petrić, V. (2006). Atlas svijeta Leksikografskog zavoda "Miroslav Krleža". Kartografija i geoinformacije, 5(6), 140-141. http://hrcak.srce.hr/8744 (10. 03. 2017) (in Croatian)

[11] Kljajić, I. \& Lapaine, M. (2007). Dva bečka rukopisna atlasa s kartografskim prikazima hrvatskih gradova iz 16. stoljeća. Kartografija $i$ geoinformacije, 6(Posebanbroj), 180-197. http://hrcak.srce.hr/index.php?id_clanak_jezik=20116\&sho $\mathrm{w}=$ clanak (10. 03. 2017) (in Croatian)

[12] Lechthaler, M. \& Stadler, A. (2007). Značenje kartografske geovizualizacije prostornih podataka u multimedijskom interaktivnom atlasnom informacijskom sustavu. Kartografija $i \quad$ geoinformacije, 6(7), 4-18. http://hrcak.srce.hr/13173 (10. 03. 2017) (in Croatian)

[13] Tutić, D. \& Tanfara, A. (2007). Interaktivni atlas svijeta istraživanje mogućnosti internetske kartografije. Kartografija $i$ geoinformacije, 6(Posebanbroj), 82-93. http://hrcak.srce.hr/13120 (10. 03. 2017) (in Croatian)

[14] Srbinoski, Z. (2009). Osnovna državna karta za GIS - nova digitalna topografska karta Republike Makedonije. Kartografija $i \quad$ geoinformacije, $8(12), \quad 18-31$. $\mathrm{http}: / /$ hrcak.srce.hr/48183?lang=en (10. 03. 2017) (in Croatian)

[15] Lapaine, M. (2010). Pregledna karta Primorsko-goranske županije. Kartografija $i$ geoinformacije, 9(13), 78-81. http://hrcak.srce.hr/index.php?show=clanak\&id_clanak_jez $\mathrm{ik}=86166(10.03 .2017)$ (in Croatian)

[16] Frangeš, S. (2012). Usporedba dviju karata Splitskodalmatinske županije. Kartografija i geoinformacije, 11(18), 140-147. http://hrcak.srce.hr/index.php?show=clanak\&id_ clanak jezik $=144298$ (10.03. 2017) (in Croatian)

[17] Frangeš, S. (2013). Analiza i usporedba triju turističkoplaninarskih karata - Otok Vis, Park prirode Biokova i Orjen-Sniježnica. Kartografija i geoinformacije, 12(20), 104-113. http://hrcak.srce.hr/133748 (10. 03. 2017) (in Croatian)

[18] Tutić, D. \& Frangeš, S. (2012). Osvrt na planove gradova turističkih ureda na Jadranu. Kartografija i geoinformacije, 11(18), 148-155. http://hrcak.srce.hr/97974 (10. 03. 2017) (in Croatian) 


\section{Contact information:}

Stanislav FRANGEŠ, Full time professor

Institute of Cartography and Photogrammetry,

Faculty of Geodesy, University of Zagreb,

Kačićeva 26, 10000 Zagreb, Croatia

E-mail: sfranges@geof.hr

Damir ŠANTEK, PhD

State Geodetic Administration, Director-General

Gruška 20, 10000 Zagreb, Croatia

E-mail: Damir.Santek@dgu.hr

Darko FUDURIĆ, MSc, Mech. Eng

Dinamika Ltd.

Miroslava Krleže 25, 47000 Karlovac, Croatia

E-mail: dfuduric@gmail.com 